\title{
EMBRYOTOXIC EFFECT OF BULL SEMINAL RIBONUCLEASE AND TISSUE ABSORPTION STUDIES IN RATS
}

\author{
J. MATOUŠEK \\ Czechoslovak Academy of Sciences, Institute of Animal Physiology and Genetics, \\ Liběchov, Czechoslovakia
}

(Received 7th October 1974)

A protein substance responsible for embryotoxic and aspermatogenic effects in mice was isolated from bull seminal vesicle fluid by Dostál \& Matoušek (1973) and its ribonuclease activity was determined (Matoušek, Pavlok, Dostál \& Grozdanovič, 1973). This enzyme also caused disturbances of embryonic development in guinea-pigs and rabbits (Matoušek, Fulka \& Pavlok, 1973).

The present paper presents an account of the embryotoxic effect of the enzyme (AS RNase) in rats and the results of the study of absorption and binding of AS RNase by various embryonic and adult tissues.

Wistar rats weighing 250 to $270 \mathrm{~g}$ and 5 to 10 days pregnant were given a single subcutaneous injection of $40 \mathrm{mg}$ pure AS RNase, together with 40,80 or $120 \mathrm{mg}$ partly purified ribonuclease designated AS RNase (BS) (Dostál \& Matoušek, 1973) diluted in $2 \mathrm{ml}$ of 0.1 M-trisodium citrate. The aspermatogenic activity (Matoušek, Pavlok, Dostál \& Grozdanovič, 1973) of AS RNase (BS) had 50 to $55 \%$ of the efficiency of pure AS RNase. Control pregnant rats were injected with $2 \mathrm{ml}$ sodium citrate without the enzyme. The pregnant rats were killed 10 days after the injections and the number of embryos was determined.

The sensitivity to AS RNase of young rats was also studied 1, 5, 10, 20 and 160 days after birth. The toxic doses of this enzyme to young rats were determined and compared with the effect of bovine pancreatic A RNase (KochLight, England).

Blood samples were taken from the pregnant rats at autopsy for determination of the numbers of red and white blood cells. Differential counts of 100 to 200 cells were made on smears stained with May-Grünwald's and Giemsa's stain.

The antitesticular effect of AS RNase (Matoušek, Pavlok, Dostál \& Grozdanovič, 1973) was used in a study of the capacity of rat tissue homogenates to absorb it. The embryos were taken from 19- to 21-day pregnant rats. The adult tissues were prepared from rats with body weights of 240 to $350 \mathrm{~g}$. About 300 to $500 \mathrm{mg}$ tissue were homogenized in a glass homogenizer with phosphate buffer, $\mathrm{pH} 7 \cdot 2$, in a $1: 5$ ratio. Following centrifugation at $1000 \mathrm{~g}$, the tissue (about $0.5 \mathrm{ml}$ ) was mixed and carefully stirred with a $1 \%$ solution of AS RNase (BS) or a $0.5 \%$ solution of pure AS RNase in a $1: 1$ ratio $(v / v)$. After incubation at room temperature for $1 \mathrm{hr}$, the mixture was centrifuged and $0.02 \mathrm{ml}$ of the 
supernatant was injected into the left testes of four to six sexually mature mice. Unabsorbed AS RNase or $0.9 \% \mathrm{NaCl}$ was injected into the left testes of control mice. The difference in the weight index (Matoušek, 1969) of the left and right testes of the control group of mice injected with $0.9 \% \mathrm{NaCl}$ (Group A) represented the value for the $100 \%$ absorption of AS RNase, while that for the second control group injected with unabsorbed AS RNase (Group B) represented the value for zero absorption. The difference in the values of the weight indices of the left and right testes of the mice in the two control groups provided the reference data for calculation of the \% absorption capacities of all the homogenized tissues used for the AS RNase absorption. The capacities were calculated from the following formula: $A b=\left(D^{B}-D^{E}\right) \times 100 / D^{B}-D^{A}$, where $\mathrm{Ab}=\%$ absorption, $\mathrm{D}^{\mathrm{A}}=$ difference between the weight index of the left testis injected with $0.9 \% \mathrm{NaCl}$ and the uninjected right testis, $\mathrm{D}^{\mathrm{B}}=$ difference between the weight index of the left testis injected with the unabsorbed AS RNase and the uninjected right testis, $D^{\mathrm{E}}=$ difference between the weight index of the left testis injected with AS RNase absorbed with the tissue homogenate and the uninjected right testis.

Table 1. Incidence of embryonic mortality in pregnant rats after AS RNase injections

\begin{tabular}{|c|c|c|c|c|c|c|}
\hline \multicolumn{2}{|c|}{$\begin{array}{c}\text { Dose of } \\
\text { AS RNase }\end{array}$} & \multirow[t]{2}{*}{$\begin{array}{c}\text { No. of } \\
\text { pregnant } \\
\text { rats } \\
\text { injected }\end{array}$} & \multicolumn{2}{|c|}{$\begin{array}{c}\text { No. of rats pregnant } \\
10 \text { days after } \\
\text { AS RNase injections }\end{array}$} & \multicolumn{2}{|c|}{$\begin{array}{l}\text { No. of living embryos } \\
10 \text { days after } \\
\text { AS RNase injections in }\end{array}$} \\
\hline$m g$ & $\begin{array}{c}m g / g \\
b o d y w t\end{array}$ & & Total & $\%$ & $\begin{array}{c}\text { Untreated } \\
\text { rats }\end{array}$ & $\begin{array}{c}\text { Injected } \\
\text { rats }\end{array}$ \\
\hline $\begin{array}{l}\text { Sodium citrate } \\
\text { (control) } \\
40 \text { (pure) } \\
40(\mathrm{BS}) \\
80 \text { (BS) } \\
120 \text { (BS) }\end{array}$ & $\begin{array}{l}0 \cdot 154 \\
0 \cdot 156 \\
0 \cdot 313 \\
0 \cdot 470\end{array}$ & $\begin{array}{r}9 \\
4 \\
7 \\
14 \\
9\end{array}$ & $\begin{array}{l}8 \\
1 \\
7 \\
7 \\
4\end{array}$ & $\begin{array}{r}88 \\
25 \\
100 \\
50 \\
44\end{array}$ & $\begin{array}{l}10 \cdot 75 \pm 1 \cdot 71 \\
11 \cdot 0 \\
10 \cdot 57 \pm 2 \cdot 49 \\
9 \cdot 14 \pm 3 \cdot 30 \\
8 \cdot 25 \pm 2 \cdot 50\end{array}$ & $\begin{array}{c}9 \cdot 55 \pm 3.96 \\
2 \cdot 73 \pm 8 \cdot 12^{*} \\
10 \cdot 57 \pm 2 \cdot 49 \\
4 \cdot 50 \pm 4 \cdot 11^{* *} \\
3 \cdot 55 \pm 4.06^{* *}\end{array}$ \\
\hline
\end{tabular}

BS, partly purified AS RNase.

* $0.05>P>0.02 ; * * P<0.01$.

Each embryonic and adult tissue was used five times from five or more rats for calculation of the absorption efficiency.

The homogenized tissues used for the absorption studies were also used for indirect immunofluorescence. This technique was performed according to the method described by Batty \& Walker (1969). Rabbit antisera against pure AS RNase and bovine pancreatic A RNase were used.

Embryonic death was evoked during the 5th to 10th days of pregnancy (Table 1). The sensitivity of the embryonic tissues to the enzyme did not cease at birth. On the first day after birth, injection of $0.16 \mathrm{mg}$ pure AS RNase/g body weight caused the death of fourteen out of sixteen animals within $48 \mathrm{hr}$. Doses of 0.33 $\mathrm{mg}, 0.50 \mathrm{mg}$, and $1.04 \mathrm{mg}$ AS RNase were needed to cause the death of all injected animals (four rats in each group) on the 5th, 10th and 20th day after birth, respectively. The death of adult rats could be caused by a dose $(0.88 \mathrm{mg} / \mathrm{g}$ body weight) which was five times that required for 1-day-old rats. Bovine 
pancreatic A RNase injected in the same amount as AS RNase caused no pathological changes.

Embryotoxic doses of AS RNase injected into pregnant rats 10 days after the AS RNase injection did not cause statistically significant changes in the number of red and white blood cells or in the differential counts of the white cells.

Standard solutions of AS RNase absorbed with embryonic or adult rat tissues had different antitesticular effects on mouse testes according to the tissues used for absorption (Table 2). Homogenates of embryonic brain, heart, lungs,

Table 2. Absorption of AS RNase by embryonic and adult rat tissues

\begin{tabular}{|c|c|c|c|}
\hline \multirow{2}{*}{ Tissue } & \multirow{2}{*}{$\begin{array}{c}\text { Mean } \\
\text { absorption } \\
\pm S . E . M . \\
(\%)\end{array}$} & \multicolumn{2}{|c|}{$\begin{array}{c}\text { Range of indirect } \\
\text { immunofluorescence } \dagger\end{array}$} \\
\hline & & $\underset{\substack{\text { tissue } \\
\text { ASNase }}}{ }$ & $\begin{array}{c}\text { Pancreatic } \\
\text { A RNase } \\
\text { tissue }\end{array}$ \\
\hline $\begin{array}{l}\text { Brain } \\
\text { Embryonic } \\
\text { Adult }\end{array}$ & $\begin{array}{l}41 \pm 25^{*} \\
14 \pm 18\end{array}$ & $+t_{0}++$ & 0 to \pm \\
\hline $\begin{array}{l}\text { Heart } \\
\text { Embryonic } \\
\text { Adult }\end{array}$ & $\begin{array}{l}60 \pm 31^{* *} \\
22 \pm 19\end{array}$ & $+\underset{0}{\text { to }}++$ & 0 to + \\
\hline $\begin{array}{l}\text { Lung } \\
\text { Embryonic } \\
\text { Adult }\end{array}$ & $\begin{array}{l}56 \pm 26^{*} \\
23 \pm 20\end{array}$ & $\begin{array}{l}++ \\
0 \text { to }+\end{array}$ & $0 \stackrel{ \pm}{ \pm} \pm$ \\
\hline $\begin{array}{l}\text { Stomach } \\
\text { Embryonic } \\
\text { Adult }\end{array}$ & $\begin{array}{l}69 \pm 38 * \\
29 \pm 21\end{array}$ & $\begin{array}{l}++ \\
0 \text { to }++\end{array}$ & $\begin{array}{l}0 \text { to }+ \\
0 \text { to }+\end{array}$ \\
\hline $\begin{array}{l}\text { Kidney } \\
\text { Embryonic } \\
\text { Adult }\end{array}$ & $\begin{array}{l}45 \pm 19^{*} \\
12 \pm 28\end{array}$ & $\begin{array}{l}+ \text { to }++ \\
0 \text { to } \pm\end{array}$ & $\begin{array}{l}0 \\
0\end{array}$ \\
\hline $\begin{array}{l}\text { Liver } \\
\text { Embryonic } \\
\text { Adult }\end{array}$ & $\begin{array}{l}50 \pm 17 \\
22 \pm 34\end{array}$ & $\underset{ \pm \text { to }}{++}$ & $\begin{array}{c}0 \\
0 \text { to } \pm\end{array}$ \\
\hline $\begin{array}{l}\text { Spleen } \\
\text { Embryonic } \\
\text { Adult }\end{array}$ & $\begin{array}{l}65 \pm 35 \\
38 \pm 22\end{array}$ & $\begin{array}{l}+ \text { to }+++ \\
0 \text { to }++\end{array}$ & $\begin{array}{l}0 \text { to }+ \\
0 \text { to } \pm\end{array}$ \\
\hline $\begin{array}{l}\text { Uterus } \\
\text { Adult }\end{array}$ & $14 \pm 16$ & 0 to + & 0 to + \\
\hline $\begin{array}{l}\text { Testis } \\
\text { Adult }\end{array}$ & $54 \pm 13^{*}$ & 0 to + & 0 \\
\hline $\begin{array}{l}\text { Trophoblast } \\
\text { Embryonic }\end{array}$ & $29 \pm 11$ & 0 & 0 \\
\hline
\end{tabular}

* $0.05>P>0.01 ; * * P<0.01$.

+0 , no fluorescence; \pm , faint fluorescence; + , clear fluorescence; ++ , strong fluorescence; +++ , very strong fluorescence.

stomach and kidney absorbed more AS RNase than the same tissues of adult rats. Embryonic and adult liver and spleen tissues did not differ significantly in their capacity to absorb AS RNase, but the embryonic liver and spleen absorbed significantly more AS RNase compared to the same tissues of the rats in control Group B. In the adult rats, only testicular tissue absorbed AS RNase. The uterus and trophoblast showed weak absorption. 
All the homogenized tissues, in which absorption of the AS RNase solution was associated with a decreased antitesticular effect of this enzyme, showed positive fluorescence in vitro (Table 2). All the embryonic tissues were fluorescence-positive, but, of the adult tissues, only some samples of stomach and spleen showed positive fluorescence. Bovine pancreatic A RNase was absorbed very weakly by rat tissues (Table 2).

The absorption experiments and the indirect immunofluorescence technique showed that while AS RNase was bound by embryonic tissues, there was little absorption activity by the same organs in adult rats. It seems therefore that the damaging effect of AS RNase is related to the different affinity of certain cells for the enzyme. This different affinity of AS RNase is accentuated when the fluorescence reaction of tissue homogenates to which AS RNase was added is compared with the same tissues in which this enzyme was replaced by bovine pancreatic A RNase. The difference in absorption and indirect immunofluorescence between embryonic and adult tissues has also been found in mouse ( J. Matoušek, unpublished data) and human tissues (J. Matoušek and K. Fortýn, unpublished work).

I express my thanks to Mrs M. Hokešová and Dr F. Zavřel for technical collaboration.

\section{REFERENCES}

BatTy, J. \& WaLKeR, P. D. (1969) The use of the fluorescent labelled antibody technique for the detection and differentiation of bacterial species. In Immunobiological Standardization, Vol. 4, pp. 72104. Karger, Basel.

DostÁl, J. \& MATOUŠEK, J. (1973) Isolation and some chemical properties of aspermatogenic substance from bull seminal vesicle fluid. F. Reprod. Fert. 33, 263-274.

Matoǔse, J. (1969) Effects on spermatogenesis in guinea-pigs, rabbits and sheep after their immunization with sexual organ fluids of bulls. F. Reprod. Fert. 19, 63-72.

Matoušex, J., Fulka, J. \& Pavlok, A. (1973) Effect of ribonuclease fractions isolated from bull seminal vesicle fluid on embryonic mortality in guinea pigs, rabbits and pigs. Int. F. Fert. 18, 13-16.

Matoušek, J., Pavlok, A., Dostál, J. \& Grozdanovič, J. (1973) Some biological properties of bull seminal vesicle aspermatogenic substance and its effect on mice. F. Reprod. Fert. 34, 9-22. 